\title{
COPROSTANOL DISTRIBUTION IN MARINE SEDIMENTS OFF SOUTHWESTERN TAIWAN
}

\author{
Woei-Lih Jeng, ${ }^{a *}$ Joe Wang ${ }^{a} \&$ Bor-Cheng $\operatorname{Han}^{b}$ \\ ${ }^{a}$ Institute of Oceanography, National Taiwan University, Taipei, Taiwan, Republic of China \\ ${ }^{b}$ School of Public Health, Taipei Medical College, Taipei, Taiwan, Republic of China
}

(Received 23 February 1996; accepted 8 July 1996)

\begin{abstract}
One of the major industries in southern Taiwan is pigfarming along the Kaoping River; some two million animals are being raised along the river banks. Excretions from pigs, treated and untreated, are discharged directly into the river and eventually carried to the sea. Twentyfour surface sediments and one sediment core off southwestern Taiwan were analyzed to determine quantitatively the extent of coprostanol addition and its distribution and to obtain the input of coprostanol over the past. Geographically, the percent coprostanol is highest around the river mouth, and decreases to about $1 \%$ at the shelf break and about $0 \%$ at a distance of approximately 40 nautical miles $(74 \mathrm{~km})$ from the river mouth. The progressive seaward decline of percent coprostanol from the river mouth can be attributed to [1] dilution of coprostanol by uncontaminated sediment and/or sediment containing relatively lower levels of coprostanol, [2] dilution of coprostanol by biogenic sterols, and [3] probably degradation of coprostanol. Further, the Kaoping Canyon sediments contain relatively high percent copros tanol; this can be attributed to [1] a more direct input of the river sediments because the canyon is well aligned with the river, [2] currents in the canyon being alternate upcanyon and downcanyon which tend to keep sediments in the canyon, and [3] the possible blocking effect of a topographic high in the canyon. A sediment core exhibits comparatively higher percent coprostanol in the top $15 \mathrm{~cm}$, indicating an increased input of coprostanol over the past 20 years. Copyright (C) 1996 Elsevier Science Ltd
\end{abstract}

Keywords: Coprostanol, sediment, wastes, river, canyon.

\section{INTRODUCTION}

Coprostanol ( $5 \beta$-cholestan-3 $\beta$-ol) has been widely used as a tracer for monitoring sewage pollution (Goodfellow et al., 1977; McCalley et al., 1980; Yde et al., 1982). Feces of man and mammals contain coprostanol as a characteristic sterol which is produced by intestinal

*To whom correspondence should be addressed. microbial reduction of cholesterol (cholest-5-en-3 $\beta$-ol) (Rosenfeld \& Gallagher, 1964; Martin et al., 1973).

The distribution of percent coprostanol in New York Bight surficial sediments shows that the highest values $(10-15 \%)$ are located in the area of the Christiaensen Basin where black silts and muds (high in TOC) are accumulating and that the amount of sewage contamination in silts of the Bight diminishes quite rapidly as a function of distance from the center of the basin (Hatcher \& McGillivary, 1979). Coprostanol concentrations in sediments decrease from the sewage outfall with distance in Sarasota Bay, Florida, and exhibit a skewed distribution in a north-south direction along the eastern shoreline (Pierce \& Brown, 1984). The progressive seaward decline of sedimentary coprostanols relative to total sterols from the outfalls in the Santa Monica Basin, southern California represents dilution of sewage by biogenic sterols (Venkatesan \& Kaplan, 1990). The distribution of coprostanol in waters and surface sediments shows a gradient of decreasing concentration from point sources down Narragansett Bay, Rhode Island (LeBlanc et al., 1992).

One of the major forms of agriculture in southern Taiwan is the pig-farming industry. The industry is virtually concentrated on the eastern bank of the Kaoping River (Pingtung county). At present, it is estimated that there are some two million animals being raised along the river banks. Treated and untreated piggery wastes are discharged directly into the river. The pig wastes including coprostanol are carried by the river water, and the sea off southwestern Taiwan is the repository for the agricultural wastes. The marine environment in this area is rather unique in terms of geomorphology. A major feature is Kaoping (submarine) Canyon, belonging to the river extension type canyon. The canyon is well aligned with the Kaoping River on land, runs across the continental shelf, continues its course southwestward onto the continental slope, and terminates at a depth of about $3000 \mathrm{~m}$ (Ma, 1963; Liu et al., 1993). The head of the canyon, cutting the continental shelf, is characterized by high and steep walls, and the cross-sectional morphology of the canyon varies from V-shaped to broadly U-shaped (Yu et al., 1991). The geologic setting of this marine environment provides us with an opportunity to study the accumulation and transport of 


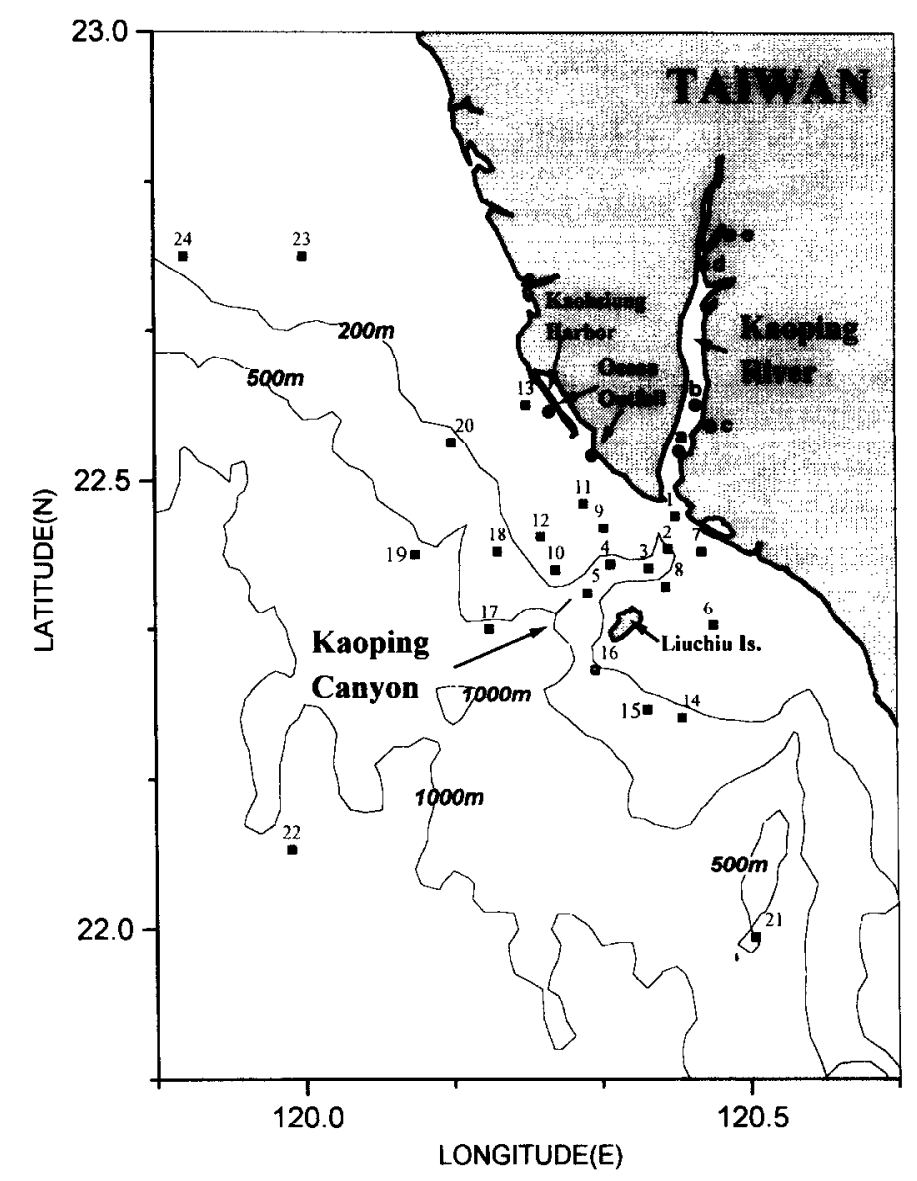

Fig. 1. Map showing sediment sample sites off southwestern Taiwan and in the Kaoping River.

coprostanol when discharged into the canyon. The purposes of this study were to investigate the accumulation, especially in the canyon, and dispersal of untreated pig wastes from the river and to obtain the history of the input of coprostanol over the past.

\section{EXPERIMENTAL}

Twenty-four surface sediments (ca. top 3-4 cm) and one sediment core (ca. $40 \mathrm{~cm}$ in length from station 5) off southwestern Taiwan were collected using a box corer on board the R/V Ocean Researcher I on 1011 Dec. 1992. In addition, 5 riverine sediments in the Kaoping River were also collected using a grab sampler for identifying sources. The locations of these samples are given in Fig. 1.

The analytical methods for the sediment samples have been given elsewhere (Jeng \& Han, 1994). Each sediment sample was freeze-dried, ground and extracted with a mixture of benzene and methanol $(1: 1)$ in a Soxhlet apparatus for $24 \mathrm{~h}$. An aliquot of 1-nonadecanol was added to the extract as the internal standard. The spiked extract was reduced in volume and saponified with $0.5 \mathrm{~N}$ methanolic $\mathrm{KOH}$. The neutral lipid was extracted with $\mathrm{n}$-hexane. The fraction containing alcohols and sterols was isolated by silica gel column chromatography. The isolated alcohols and sterols were derivatized with $N, O$-Bis(trimethylsilyl)acetamide. Alcohols and sterols (as trimethylsilyl ethers) were analyzed by capillary GC and GC-MS. An HP 5890 gas chromatograph was run with a split/splitless injector, a $30 \mathrm{~m} \times 0.25 \mathrm{~mm}$ fuscd silica column coated with bonded methyl silicone (SE-30) and a flame ionization dctcctor. A cool on-column injector, OCI-5 (SGE, Australia), was also fitted in the gas chromatograph for quantitation. Identification was made by coinjection with authentic standards. GC-MS was performed on an HP $5890 \mathrm{GC}$ and 5970B mass selective detector fitted with a direct capillary inlet and a split/ splitless injector. Oven temperature was programmed as follows: (1) $45-90^{\circ} \mathrm{C}$ at $15^{\circ} \mathrm{C} / \mathrm{min}$, (2) $90-270^{\circ} \mathrm{C}$ at $3^{\circ} \mathrm{C} /$ min, (3) $20 \mathrm{~min}$ at $270^{\circ} \mathrm{C}$, (4) $270-280^{\circ} \mathrm{C}$ at $10^{\circ} \mathrm{C} / \mathrm{min}$, and (5) $20 \mathrm{~min}$ at $280^{\circ} \mathrm{C}$. Hydrogen was used as the carrier gas. Peaks were quantified by the internal standard using a Shimadzu data processor, Chromatopac C-R6A. The precision of the method was determined by seven replicate analyses of the same sediment sample, and the relative standard deviation was $3.2 \%$ during a one-year period of analysis.

\section{RESULTS AND DISCUSSION}

In the present study, coprostanol also includes epicoprostanol $(5 \beta$-cholestan- $3 \alpha$-ol) since they both are found in the feces of man and other mammals (Eneroth et al., 1964; Kanazawa \& Teshima, 1978) and their relative distribution may vary with animal (Venkatesan \& Santiago, 1989). To eliminate the grain size effect on 
coprostanol, it is related to total sterols and expressed as percent coprostanol (i.e. percent of total sterols) (Hatcher \& McGillivary, 1979; Venkatesan \& Kaplan, 1990). Percent coprostanol is defined as the ratio of coprostanol to total sterols; total sterols are the sum of coprostanol and biogenic sterols. Biogenic sterols consist of cholesta-5,22E-dien-3 $\beta$-ol, $5 \alpha$-cholest-22E-en- $3 \beta$-ol, cholest-5-en-3 $\beta$-ol, $5 \alpha$-cholestan- $3 \beta$-ol, 24-methylcholesta-5,22E-dien-3 $\beta$-ol, 24 -methyl- $5 \alpha$-cholest-22E-en$3 \beta$-ol, 24-methylcholesta-5,24(28)-dien-3 $\beta$-ol, 24-methylcholest-5-en-3 $\beta$-ol, 24 -methyl- $5 \alpha$-cholestan- $3 \beta$-ol, 23,24dimethylcholesta-5,22E-dien-3 $\beta$-ol, 24-ethylcholesta$5,22 \mathrm{E}$-dien- $3 \beta$-ol, 24 -ethyl-5 $\alpha$-cholest-22E-en- $\beta \beta$-ol, 24 ethylcholest-5-en- $3 \beta$-ol, and 24 -ethyl-5 $\alpha$-cholestan- $3 \beta$-ol. The distribution of coprostanol off southwestern Taiwan exhibits a decrease of percent coprostanol with increasing distance from the river mouth if those stations in the canyon and station 13 (nearest to Kaohsiung Harbor) are excluded (Fig. 1). This is similar to those found in the Santa Monica Basin, southern California (Venkatesan \& Kaplan, 1990) and Narragansett Bay, Rhode Island (LeBlanc et al., 1992). Geographically, the percent coprostanol is highest around the river mouth, and decreases to about $1 \%$ at the shelf break (200 m depth) and about $0 \%$ (stations 22 and 24) at a distance of approximately 40 nautical miles $(74 \mathrm{~km})$ from the river mouth (Fig. 1). The progressive seaward decline of percent coprostanol from the river mouth can be attributed to the following processes. As sediment containing higher levels of coprostanol moves away from the river mouth, it is diluted by uncontaminated sediment and/or sediment containing relatively lower levels of coprostanol. Other processes include dilution of coprostanol by biogenic sterols and probably degradation of coprostanol since most of the study area is rather oxic (shallow and dynamic), for example, dissolved oxygen concentrations in the lower water column are $>4 \mathrm{ml} /$ litre (Hung et al., 1979), and unfavorable for the preservation of coprostanol (Nishimura \& Koyama, 1977; Bartlett, 1987). This can be seen from a rapid drop in percent coprostanol from stations 7 to 6 (17.5 to $1.4 \%$ ). Two ocean outfalls are located along the coast of Kaohsiung Harbor (Fig. 1): one nearest to station 13 discharges municipal wastes, and the other nearest to station 11 discharges industrial wastes. A high percentage found at station $13(5.2 \%)$ as compared to stations $11(3.5 \%)$ and $12(1.8 \%)$ can be ascribed to an additional contribution from the nearby ocean outfalls (Fig. 1). Besides, the contribution of coprostanol from the ocean outfalls does not seem to be predominant in the study area.

For urban sewage pollution, Grimalt et al. (1990) propose a parameter $5 \beta /(5 \beta+5 \alpha)$ for positively identifying fecal matter in water particulates and sediments if the ratio is $>0.7$, in which $5 \beta /(5 \beta+5 \alpha)$ is defined as the ratio of coprostanol to coprostanol and cholestanol $(5 \alpha-$ cholestan-3 $\beta$-ol). Although the study area has a predominant input of pig wastes, the ratio is employed and calculated for comparison purposes (Table 1). Stations 1,4 and 5 have $5 \beta /(5 \beta+5 \alpha)$ ratios $>0.7$, indicating heavy coprostanol pollution. Further, all samples can be divided into two groups: the high ratio group with $5 \beta$ / $(5 \beta+5 \alpha)=0.62-0.72$ and the low ratio group with $5 \beta /$ $(5 \beta+5 \alpha)=0.00-0.40$. The high ratio group includes stations 1-5, 7 and 8 . Stations 1, 7 and 8 are located on the continental shelf in the direction of the river flow, receiving a more direct deposition of coprostanol from the river runoff (Fig. 1). Stations 2-5 are situated in the canyon and contain high percent coprostanol (8.9$15.0 \%$ ) (Fig. 1). This result can be partially attributed to a predominant sediment supply from the river because the canyon is well aligned with the river. More important are the currents in the canyon. Feng (1988) used ADCP (Acoustic Doppler Current Profiler) and CTD (Conductivity Temperature Depth) data to study the currents of the canyon and found that below depths of $170 \mathrm{~m}$ the currents can be viewed as a periodically reciprocating motion independent of depth. Because the hydrographic characteristics and currents of the bottom water are clearly different from those of the upper water, he concluded that the bottom water can be regarded as a semiclosed system and that the driving force for bottom currents is derived from sea level changes from tidal motion, resulting in channel flows - upcanyon and downcanyon - which is the same as that reported by Shepard and Marshall (1973). They noted that bottom currents have a predominant effect on the sediment transport in canyons. We therefore conclude that the currents-alternate upcanyon and downcanyon-tend to keep sediments in the canyon, leading to the accumulation of high percent coprostanol.

It is worthy of note that along the canyon an abrupt decrease of percent coprostanol is found from stations 5 to $17(12.9$ to $1.4 \%)$ where the geologic environment changes greatly. Yu et al. (1991) describe that the canyon's head is characterized by high and steep walls ranging approximately from 280 to $550 \mathrm{~m}$ and narrow widths of $6-8 \mathrm{~km}$. Further, two cross-sectional profiles of the canyon between the two stations show a local topographic high in the central part of the canyon ( $\mathrm{Yu}$ et al., 1991) which presumably has a blocking effect on the sediment transport. Besides, currents may also play a role. A branch of the Kuroshio Current flowing north passes by southwestern Taiwan (Fan, 1982) which may help to disperse pollutants especially on the continental slope in this area.

The depth profile of coprostanol in the sediment core at station 5 cxhibits comparatively higher percent coprostanol in the upper three sections $(0-15 \mathrm{~cm})$ and virtually constant and lowcr percent coprostanol in the lower five sections $(15-40 \mathrm{~cm}$ ) (Table 2). This interesting profile indicates an increased input of coprostanol from the river (riverine samples given in Table 1) resulting from the pig-farming industry over the recent past. The sedimentation rate at $22^{\circ} 20.0^{\prime} \mathrm{N}, 120^{\circ} 19.3^{\prime} \mathrm{E}$ near station $5\left(22^{\circ} 22.40^{\prime} \mathrm{N}, 120^{\circ} 19.14^{\prime} \mathrm{E}\right)$ was estimated to be $0.72 \mathrm{~cm} / \mathrm{y}$ by the ${ }^{210} \mathrm{~Pb}$ technique (Tsai \& Chung, 1989). By using this rate and assuming constant sedimentation rate, the time span for input of high levels of 
Table 1. Data of surface sediments

\begin{tabular}{|c|c|c|c|c|c|c|}
\hline Sample & Depth (m) & Coprostanol $^{a}(\mathrm{ng} / \mathrm{g})$ & Cholestanol (ng/g) & $\mathrm{R}^{h}$ & Total $^{c}$ sterols $(\mathrm{ng} / \mathbf{g}$ ) & $\%$ Coprostanol $^{a}$ \\
\hline 1 & 150 & 434 & 165 & 0.72 & 2490 & 17.4 \\
\hline 2 & 290 & 822 & 373 & 0.69 & 5480 & 15.0 \\
\hline 3 & 368 & 552 & 311 & 0.64 & 6210 & 8.9 \\
\hline 4 & 450 & 354 & 144 & 0.71 & 2610 & 13.6 \\
\hline 5 & 505 & 820 & 321 & 0.72 & 6350 & 12.9 \\
\hline 6 & 44 & 44 & 171 & 0.20 & 3210 & 1.4 \\
\hline 7 & 20 & 775 & 348 & 0.69 & 4430 & 17.5 \\
\hline 8 & 70 & 684 & 418 & 0.62 & 6940 & 9.9 \\
\hline 9 & 23 & 105 & 159 & 0.40 & 2510 & 4.2 \\
\hline 10 & 151 & 81 & 241 & 0.25 & 3700 & 2.2 \\
\hline 11 & 24 & 74 & 155 & 0.33 & 2100 & 3.5 \\
\hline 12 & 117 & 42 & 136 & 0.24 & 2290 & 1.8 \\
\hline 13 & 22 & 130 & 208 & 0.38 & 2490 & 5.2 \\
\hline 14 & 255 & 22 & 207 & 0.10 & 2890 & 0.8 \\
\hline 15 & 258 & 65 & 292 & 0.18 & 4950 & 1.3 \\
\hline 16 & 238 & 53 & 276 & 0.16 & 4840 & 1.1 \\
\hline 17 & 478 & 47 & 184 & 0.20 & 3370 & 1.4 \\
\hline 18 & 280 & 24 & 125 & 0.16 & 1800 & 1.3 \\
\hline 19 & 579 & 42 & 237 & 0.15 & 4250 & 1.0 \\
\hline 20 & 278 & 9 & 82 & 0.10 & 1290 & 0.7 \\
\hline 2.1 & 252 & 7 & 88 & 0.07 & 1090 & 0.6 \\
\hline 22 & 990 & n.d. ${ }^{e}$ & 51 & 0.00 & 794 & 0.0 \\
\hline 23 & 151 & 16 & 154 & 0.09 & 2250 & 0.7 \\
\hline 24 & 181 & n.d. & 35 & 0.00 & 451 & 0.0 \\
\hline a & $c a 1$ & 11900 & 2630 & 0.82 & 46800 & 25.4 \\
\hline b & $c a 1$ & 835 & 313 & 0.73 & 4980 & 16.8 \\
\hline$c^{\prime}$ & $c a 1$ & 58200 & 13000 & 0.82 & 199000 & 29.2 \\
\hline d & ca 1 & 2820 & 648 & 0.81 & 14100 & 20.0 \\
\hline $\mathrm{e}^{\prime}$ & $c a 1$ & 35300 & 5660 & 0.86 & 130000 & 27.2 \\
\hline
\end{tabular}

"Including epicoprostanol.

${ }^{h} \mathrm{R}=5 \beta /(5 \beta+5 \alpha)=$ coprostanol $/($ coprostanol + cholestanol $)$.

'Total sterols $=$ coprostanol + biogenic sterols.

$\triangleleft \%$ Coprostanol $=$ coprostanol $/$ total sterols.

"n.d. = less than $5 \mathrm{ng} / \mathrm{g}$.

Collected from tributaries which received pig wastes directly from pig farms.

coprostanol into the canyon is approximately 20 years. This may imply that pig production has substantially increased over the recent past. From the statistics of pig production in Taiwan over the past (Fig. 2), it shows that pig production has progressively increased during the last 20 years or so. Our estimate from coprostanol data from the core is in good agreement with the statistical data if a similar pig production increase in the Kaoping River area (major pig-farming over Taiwan) is

Table 2. Data of the sediment core from station 5

\begin{tabular}{lccc} 
Core $^{a}$ section & $\begin{array}{c}\text { Coprostanol } \\
(\mathrm{ng} / \mathrm{g})\end{array}$ & $\begin{array}{c}\text { Total sterols }^{c} \\
(\mathrm{ng} / \mathrm{g})\end{array}$ & \% Coprostanol $^{d}$ \\
\hline $1(0-5 \mathrm{~cm})$ & 1050 & 8110 & 12.9 \\
$2(5-10 \mathrm{~cm})$ & 1290 & 10200 & 12.6 \\
$3(10-15 \mathrm{~cm})$ & 2480 & 14200 & 17.5 \\
$4(15-20 \mathrm{~cm})$ & 368 & 4780 & 7.7 \\
$5(20-25 \mathrm{~cm})$ & 313 & 4560 & 6.9 \\
$6(25-30 \mathrm{~cm})$ & 313 & 4490 & 7.0 \\
$7(30-35 \mathrm{~cm})$ & 406 & 5640 & 7.2 \\
$8(35-40 \mathrm{~cm})$ & 436 & 6480 & 6.7 \\
\hline
\end{tabular}

${ }^{a}$ Numbered from the core top and sectioned at $5 \mathrm{~cm}$ intervals. ${ }^{b}$ Including epicoprostanol.

Total sterols $=$ coprostanol + biogenic sterols.

$d \%$ Coprostanol $=$ coprostanol $/$ total sterols. assumed. It is also noted that an extremely high percent coprostanol is found in section $3(10-15 \mathrm{~cm})$, corresponding to the time period for sediment deposition between 1971 and 1978. This could be due possibly to a high sedimentation rate from episodic events such as large discharges or floods from the river. In fact, there were two severe floods in southwestern Taiwan during this period. A mid-August (1975) heavy storm caused by typhoon Nina resulted in severe flooding in southwestern Taiwan (Water Resources Planning Commission, 1976). Typhoon Thelma landing on south Taiwan (July 25, 1977) and bringing in extraordinary amounts of rainfall caused severe flooding (Water Resources Planning Commission, 1978).

In the above discussion, two indices are adopted: one is percent coprostanol (Hatcher \& McGillivary, 1979; Venkatesan \& Kaplan, 1990); the other is the $5 \beta /$ $(5 \beta+5 \alpha)$ ratio (Grimalt et al., 1990). Up to the present, there is no consensus among researchers as to which index is a better indicator for monitoring coprostanol. A plot of percent coprostanol versus $5 \beta /(5 \beta+5 \alpha)$ for the 29 samples is shown in Fig. 3. Curve fitting to the data points shows strong correlation $(r=0.9760$, $p<0.01$ ), indicating that the two indices are equally suitable for monitoring coprostanol. 


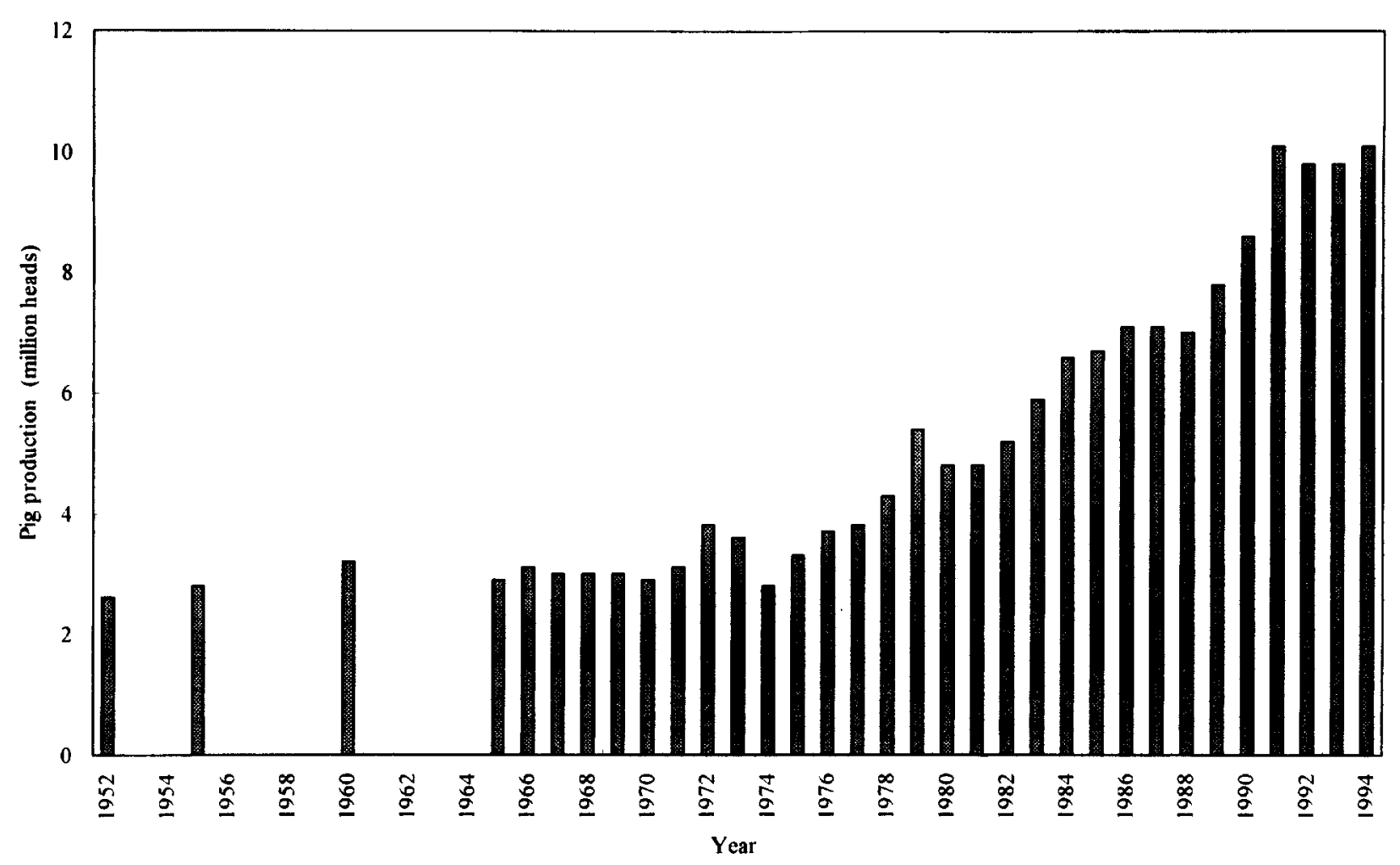

Fig. 2. Pig production in Taiwan over time (data from Council for Economic Planning and Development, 1995).

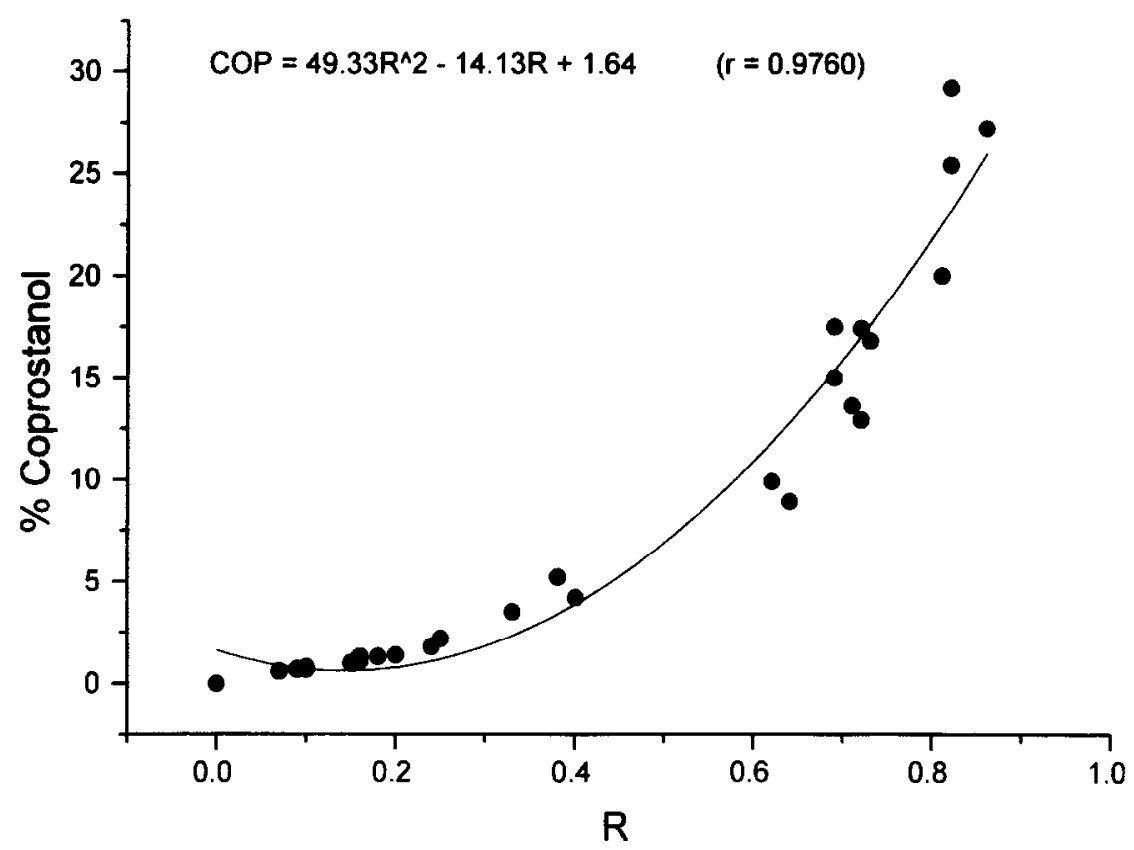

Fig. 3. Plot of percent coprostanol versus $5 \beta /(5 \beta+5 \alpha)$, represented by $\mathrm{R}$, for 24 marine and 5 riverine samples.

\section{CONCLUSIONS}

1. In general, the distribution of the percent coprostanol in sediments off southwestern Taiwan decreases with increasing distance from the Kaoping River mouth.

2. Comparatively higher percent coprostanol found in Kaoping Canyon can be attributed to [1] a direct sediment input from the Kaoping River, [2] alternate upcanyon and downcanyon currents tending to keep sediments from dispersal, and [3] possible blocking effect on sediment transport by a topographic high along the canyon in an area crossing the shelf break.

3. Relatively higher percent coprostanol in the top $15 \mathrm{~cm}$ of a sediment core suggests a substantial increase in pig waste input over the past 20 years. 


\section{ACKNOWLEDGEMENTS}

We would like to thank the captain, crew and technicians of the $\mathrm{R} / \mathrm{V}$ Ocean Researcher 1 for help with marine sediment collection. Special thanks go to $\mathrm{Mr}$. P. J. Meng for help with collecting riverine samples. We thank one anonymous reviewer for comments. This study was financially supported by the National Science Council, Republic of China (grant no. NSC83-0209M002A-011).

\section{REFERENCES}

Bartlett, P. D. (1987). Degradation of coprostanol in an experimental system. Mar. Pollut. Bull., 18, 27-29.

Council for Economic Planning and Development (1995). Taiwan Statistical Data Book, p. 80. Executive Yuan, Taipei, Taiwan, Republic of China.

Eneroth, P., Hellstrom, K. \& Ryhage, R. (1964). Identification and quantification of neutral fecal steroids by gas-liquid chromatography and mass spectrometry: studies of human excretion during two dietary regimens. J. Lipid Res., 5, 245262

Fan, K. L. (1982). A study of water masses in Taiwan Strait. Acta Oceanogr. Taiwanica, 13, 140-153.

Feng, S. T. (1988). The variation of bottom currents in Kaoping Canyon. M. S. Thesis, National Taiwan University, Taipei, Taiwan.

Goodfellow, R. M., Cardoso, J., Eglinton, G., Dawson, J. P. \& Best, G. A. (1977). A faecal sterol survey in the Clyde Estuary. Mar. Pollut. Bull, 8, 272-276.

Grimalt, J. O., Fernandez, P., Bayona, J. M. \& Albaiges, J. (1990). Assessment of fecal sterols and ketones as indicators of urban sewage inputs to coastal waters. Environ. Sci. Technol., 24, 357-363.

Hatcher. P. G. \& McGillivary, P. A. (1979). Sewage contamination in the New York Bight. Coprostanol as an indicator. Environ. Sci. Technol., 13, 1225-1229.

Hung, T. C., Ko, M. C. \& Tsai, C. C. H. (1979). Primary productivity and chemical nutrients along the southern coast of Taiwan. Acta Oceanogr. Taiwanica, 9, 23-38.

Jeng, W. L. \& Han, B. C. (1994). Sedimentary coprostanol in Kaohsiung Harbour and the Tan-Shui Estuary, Taiwan. Mar. Pollut. Bull., 28, 494-499.

Kanazawa, A. \& Teshima, S. (1978). The occurrence of coprostanol, an indicator of faecal pollution, in sea water and sediments. Oceanol. Acta, 1, 39-44.

LeBlanc, L. A., Latimer, J. S., Ellis, J. T. \& Quinn, J. G. (1992). The geochemistry of coprostanol in waters and surface sediments from Narragansett Bay. Estuar. Coast. Shelf Sci., 34, 439-458.

Liu, C. S., Lundberg, N., Reed, D. L. \& Huang, Y. L. (1993) Morphological and seismic characteristics of the Kaoping Submarine Canyon. Mar. Geol., 111, 93-108.

Ma, T. Y. H. (1963). Twin origin of the submarine canyons around Taiwan and the Quaternary glaciation in Taiwan as basis for refutation of the turbidity current theory and the so called 'Great Ice Age' as due to universal lowering of temperature. Petrol. Geol. Taiwan, 2, 209-219.

Martin, W. J., Ravi Subbiah, M. T., Kottke, B. A., Birk, C. C \& Naylor, M. C. (1973). Nature of fecal sterols and intestinal bacterial flora. Lipids, $\mathbf{8}, 208-215$

McCalley, D. V., Cooke, M. \& Nickless, G. (1980). Coprostanol in Severn Estuary sediments. Bull. Environ. Contam. Toxicol., 25, 374-381.

Nishimura, M. \& Koyama, T. (1977). The occurrence of stanols in various living organisms and the behavior of sterols in contemporary sediments. Geochim. Cosmochim. Acta, 41, 379-385.

Pierce, R. H. \& Brown, R. C. (1984). Coprostanol distribution from sewage discharge into Sarasota Bay, Florida. Bull. Environ. Contam. Toxicol., 32, 75-79.

Rosenfeld, R. S. \& Gallagher, T. F. (1964). Further studies of the biotransformation of cholesterol to coprostanol. Steroids, 4, 515-520.

Shepard, F. P. \& Marshall, N. F. (1973). Currents along floors of submarine canyons. Amer. Assoc. Petrol. Geol. Bull., 57, 244264.

Tsai, S. W. \& Chung, Y. (1989). Pb-210 in the sediments of Taiwan Strait. Acta Oceanogr. Taiwanica, 22, 1-13.

Venkatesan, M. I. \& Kaplan, I. R. (1990). Sedimentary coprostanol as an index of sewage addition in Santa Monica Basin, southern California. Environ. Sci. Technol., 24, 208214

Venkatesan, M. I. \& Santiago, C. A. (1989). Sterols in ocean sediments: noval tracers to examine habitats of celaceans, pinnipeds, penguins and humans. Mar. Biol., 102 , 431-437.

Water Resources Planning Commission (1976). Hydrological Year Book of Taiwan Republic of China 1975, p. 10. Ministry of Economic Affairs, Taipei, Taiwan, Republic of China.

Water Resources Planning Commission (1978). Hydrological Year Book of Taiwan Republic of China 1977, p. 10. Ministry of Economic Affairs, Taipei, Taiwan, Republic of China.

Yde, M., DeWulf, E., DeMaeyer-Cleempoel, S. \& Quaghebeur, D. (1982). Coprostanol and bacterial indicators of faecal pollution in the Scheldt Estuary. Bull. Environ. Contam. Toxicol., 28, 129-134.

Yu, H. S., Huang, C. S. \& Ku, J. W. (1991). Morphology and possible origin of the Kaoping submarine canyon head off southwest Taiwan. Acta Oceanogr. Taiwanica, 27, 40-50. 